\title{
THE PEDAGOGICAL CONDITION OF STUDENT TEACHERS
}

\author{
Eva Vyskočilová, Vlastimil Švec
}

\begin{abstract}
The paper outlines one of the new approaches to student teachers education - the so-called psychosomatic approach. It is based on the notion of pedagogical condition which expresses the organizing of body, mental and also moral dispositions of student teachers to acting. Pedagogical condition may be developed by means of various psychosomatic disciplines which especially include the so called (Inter)acting with the Inner Partner. The authors characterize this discipline, which was introduced to Czech awareness by Ivan Vyskočil from the Theatre Faculty in Prague. They also draw attention to finding out the increase in pedagogical condition of student teachers in (Inter)acting with the Inner Partner.
\end{abstract}

\section{Keywords}

Teacher education, pedagogical condition, (Inter)acting with the Inner partner.

\section{The Paper's Context}

Changes in the role of teachers are linked to changes in the teacher education. Above all, it is the curriculum that is being changed, and its realisation and implementation also presume changes in the thinking-patterns and behaviour of student teachers. Pedagogical knowledge and the thinking processes of teachers among other issues have been, up until now, at the forefront of research studies. However, the wide variety and range of pedagogical situations which a teacher encounters in schools require a deeper degree of preparation of the personality of student teachers in order for them to behave authentically and creatively in such situations. This preparation process is not only based on concrete pedagogical knowledge - but also upon the personality "settings" of these students vis-a-vis unexpected situations. We have chosen to entitle this setting the "Pedagogical Condition".

According to I. Vyskočil, condition is, "a certain maturity, preparation, readiness to react rapidly and flexibly and, even the need, desire, or internal 
urge to act publicly, to act and to behave, and to experience directly, without barriers, spontaneously, creatively and productively, independently and responsibly. In feedback loops, in a high-quality manner" (Vyskočil, 2000, p. 7).

The Pedagogical Condition not only involves students ' thought processes, but also their voice, speech and movement. Put simply, it is associated with a person's whole body, or respectively with their whole personality. For this reason, it is possible to entitle this - until the present day, unusual approach to the teacher education, a "Psychosomatic Approach".

This holistic approach is based upon the well-known, but often not respected fact that, in the preparation of students teachers, knowledge-acquisition does not take place within the head of a person, but rather throughout their bodies and that the teacher education should include their preparation for the rational and emotional mastery of social situations as well as for anticipating the same in one's imaginings. The Psychosomatic Approach is founded upon the encouragement of the development of the personality of student teachers which should be oriented towards their "public behaviour" being - (as far as possible) - the presentation, realisation, 'radiation' of a fully-aware, communicative, creative, responsible behaviour and experiencing of situations - a consciously moral personality" (Vyskočil, 2000, p. 6).

In the workplaces of the co-authors of this paper, (and especially in the Department of Authorial Creativity and Pedagogy, Theatre Faculty in Prague), the pedagogical condition of students is developed through psychosomatic disciplines, among which and above all are subjects like (Inter)acting with the Inner Partner, Voice and Speech Education, Movement Education and Author Readings. Since the core discipline is (Inter)acting with the Inner Partner, we shall devote our further attentions to it in this paper.

\section{(Inter)acting with the Inner Partner}

(Inter)acting with the Inner Partner (further only AIP) is based upon the experience and knowledge that man, usually when alone, speaks to or plays with - themselves. Their internal partner appears to them and calls to them. And in AIP, the whole point is that this dialogue with one's inner partners be reproduced publicly, within a group of their fellow colleagues-students and university-level teachers who have practical experience with this discipline and have experienced it and lived through it themselves. 
Students receive virtually no instruction whatsoever as to what they have to do, they are simply told: Try to hold a dialectical discussion with yourself. With yourself as you would with your inner partner. Ivan Vyskočil provides several recommendations for students who are beginning with AIP (Vyskočil, 2005 , pp. 20-22, and rounded-out and complemented by the personal experience and experiences of the authors of this paper):

- Do not prepare anything in advance. Inspire yourself by whatever - hereand-now, on-the-spot, comes into your mind, whatever you notice. It is necessary to make this idea public, verbally, or even - non-verbally. We will react to this idea immediately or after a while (we will respond).

- Feel, behave and act as if the others present (colleagues, the teacher) simply were not present (i.e. so-called "public aloneness").

- Concentrate, and perceptively feel what we are doing. Do not think about what to say. Do not concentrate on concentrating - since you will simply fall into a panic.

- As soon as you can, at the very first impulse you feel, give it form - act it out. But there is no need to feel an immediate duty to enact or say anything on the spot.

- Allow yourselves time to respond to this impulse. Do not hurry or rush, so that you are aware of what it is you are saying or doing; whether and how this other (inner partner) expresses themselves (i.e. whether they are already speaking or acting).

- Think of nothing. Do not think of anything. Notice what we have done, for instance - what goes on when we alter or change the position of our body, or make some gesture, etc.

- Notice where a certain sequence ends, and where opposition makes itself heard (i.e. our internal partner).

- Maintain tension - that which flows from us, "beyond the footlights", to the others. When we stiffen, for instance our hands, shoulders, are not relaxed; then we rid ourselves of the possibility of expression.

- Seek a productive anti-pole to the previous impulse; contrasts, which complement each other.

- Do not fear changes (which might even surprise us); give it expression. Accept it, act it out.

- Engage yourself fully into the dialectical discussion or behaviour; do not satisfy yourself just with voice, certain movements, grimaces, gestures.

- Enjoy the feelings from this experience and self-testing, taste it to the full. 
- Express your experience and feelings from this dialectical discussion or behaviour through self-reflexion in a written form.

AIP is an unusual discipline. It places a relatively simple requirement upon students who decide to penetrate its mysteries - that they "act". Of course, "for themselves", since we cannot do any otherwise. But with whom should they act? The answer is - with their "inner partner" in the given situation of public aloneness. They are given the opportunity to do so in an ordinary faculty auditorium, where one half is reserved for the actions and behaviour of one of them, while the others sit next to each other on seats in the second half, as the audience. However, acting out one's inner partner is not equivalent to or the same as talking to oneself, breeding self-speech.

The participants are encouraged not to think in advance about what they are going to say (or do); not to prepare themselves in advance - but rather, to begin from scratch, from nothing, from themselves within the situation. The participants are warned not to rush into things and to muffle or dampen their efforts to "be good" (in what they do) - to suppress that "norming" within themselves. That they unnecessarily judge themselves too harshly, curse themselves out, blame themselves; that they not resist activity, not be unsure of themselves, despair of themselves, not be uneasy about themselves.

Why do teachers need AIP? Teachers need creativity - they need to know how to make a difference between what to do mechanically, and where a person should not simply remain bound to a habit. They need to understand their own (forms of) expression, what they are inclined towards; where their strengths might lie, their communicativeness. They need to develop their imaginations and fantasy; to learn how to react to new situations and to anticipate other situations.

AIP requires time; it requires that student teachers rid themselves of their everyday stereotypes in their dealings not only with pupils but also with their colleagues. One university teacher (Ms. Jaroslava Pokorná), who leads AIP training sessions, writes about this in their self-reflective diary as follows: "Teachers master the art of self-presentation to a high degree, (since) their craft is winning over a class full of pupils. Stepping out before the eyes of others for them automatically means standing up for themselves (doing it well). All those who have tried dialogical acting know that they have to suffer a moment of helplessness, since this is the first time that a new, unusual, surprising thing is born within themselves; where they see themselves in a light they have never know before." 


\section{The Methodological Presumptions for Research into (Inter)acting with the Inner Partner}

We base ourselves on the fact that children express themselves in a more significant manner through changes in the positioning of their bodies and that for student teacher (adults), it is their tongue (and Language) which is the reflection as well as the picture of what is going on within their interiors. If we compare various linguistic pictures from around the world, it is not only necessary to take into consideration the differences between them, but also what is universal to them all (human body-forms and spatial experience, orientation on humanity, the categorisation of the world as well as its conceptualisation with the aide of metaphors).

We consider the observation that metaphors are far from being a matter of linguistics and language, but metaphorically-speaking, they are predominantly our conceptual system, way of thinking, of seeing the world - as being fundamental. Metaphors are primarily a phenomenon which is not a linguistic but rather a mental one (Lakoff, Johnson, 2002). Differences tend rather to be on the surface (the structuring of a event, description and assessment), while the similarities have to do with the deeper structure of our anchoring in the world. It has to do with a bodily and spatially oriented and based conceptual schema (Vaňková, Nebeská, Rímalová, Šlédrová, 2005). Similar to Cognitive Linguistics, it has its instrumentaria and creates interpenetrations and leakages between layers of linguistic materials, similar perhaps to the ethnographic study of the culture of behaviours within social groups. It does so in the form of the documentation of the "everydayness" of groups, i.e. the language of the dealings and behaviours. It is oriented on the analysis of speech interactions, on the commonness of everyday conversation, which is the most common and most significant of all social phenomena.

This gifted Lecturer of AIP was caught by surprise to discover that there was nothing to write about what AIP is, but rather she could only describe what it lead her to. It leads her to an awareness of the weight of subjective experience and a turning away from an effort to capture and comprehend AIP in words and terms. In her self-reflective diary she writes: "In AIP, personal, subjective experiences are given precedence over closed/fixed/finished shapes, results, performance. ... From this turning away from a tendency towards finished shapes, results, or performance flows an accentuated processional process, experiences tied to time, to space ... It also led her to a different understanding of the whole. We are used to understanding the term "whole" as something holding 
together, compact; often, as parts of something which belong together and to one another. Her experience with AIP led her to the experiencing of the whole as something which she may create, think up, conceive - even reveal. That this whole is never given in advance, and even - is not given even in the course of the rehearsal, since each of my further steps and actions alter, change and are reshaped and re-formed. This experience even led her to a different understanding of the subsequent shape. The whole changes throughout the entire time that I am actively engaged in it." (Musilová, 2003)

In this sense therefore, we needed to verify the hypothesis that, under certain circumstances, we can as viewers (observers, researchers) relatively reliably feel (differentiate, guess) strong moments in the dialectic event/output (presentation, sharing, communication) of another, whose acting is recorded on a video-recording. One of the most important features which it was possible to track with students of teaching was its processional character - optimal tension, concentration - and at the same time, "alienation - withdrawal"; filling of words with significance, the ability to allow oneself self-expression.

The subject of this analytic investigation is video-recordings of the (Inter) acting with the Inner Partner of students arranged in the order of their date of recording. The viewer/observer looks at these recorded performances similar to a member of the audience - in the same way as at minor events whose theme is attempts at AIP. The activity of the viewer/observer and the audience-member is determined by their openness, interest engagement and lack of prejudice. In the course of watching, the viewer/observer notices the level of their interest and attention. We consider this attention and interest as being the chief index of the moment when a connection between internal happenings, external expression of the same, and the social context occurred.

Currently, we have posed ourselves the following research questions: How far is it possible to the linked behaviour, acting and speech of the student on the video-recording? Which marked things have remained on the video-recording? What is the significance of the video-recording? Ivan Vyskočil recommends arriving at these perceptions of the recordings through kinesthesia. To teach oneself this process at the muscle tension level. When the observer learns this way of perception, they advance in perception and self-perception.

\section{Conclusion}

We have a set of video-recordings of the (Inter)acting with the Inner Partner of our students at our disposal. And we have set ourselves the following 
question: How can we "mine" from this set of recordings those phenomena which would single out and indicate growth in the pedagogical condition of student teachers. As Blaise Pascal said when he discovered the Law of Equivalent Pressures in Liquids: "I know what it is, but I don't know how I came up with it." We need therefore to become aware of the acts, forms, as Gestaltists say; or as M. Sedláková and J. Hoskovec (2002) also say: "We perceive content, but not acts."

\section{References}

LAKOFF, G., JOHNSON, M. Metafory, kterými žijeme. Brno: Host, 2002.

MUSILOVÁ, M. Proč již sedm let nejsem schopná napsat, co je dialogické jednání? In Vyskočil, I. (Ed): Hic sunt leones - o autorském herectví. Praha: AMU, 2003, pp. 51-52.

SEDLÁKOVÁ, M., HOSKOVEC, J. Od raného gestaltismu k neogestaltismu. In HOSKOVEC, J., NAKONEČNÝ, M., SEDLÁKOVÁ, M. (Ed) Psychologie XX. století. Praha: Karolinum, 2002, pp. 114-150.

VAŇKOVÁ, I., NEBESKÁ, I., SAICOVÁ-ŘÍMALOVÁ, L., ŠLÉDROVÁ, J. Co na srdci, to na jazyku: kapitoly z kognitivní lingvistiky. Praha: Karolinum, 2005.

VYSKOČIL, I. Úvodem. In: VYSKOČIL, I. (Ed.) Psychosomatický základ verejného vystupování: jeho studium a výzkum. Praha: Akademie múzických umění, 2000, pp. 5-7.

VYSKOČIL, I. Rozprava o dialogickém jednání. In: VYSKOČIL, I. A KOL. Dialogické jednání s vnitřním partnerem. Brno: Janáčkova akademie múzických umění, 2005, pp. 13-22.

\section{Contact}

doc. PhDr. Eva Vyskočilová, CSc.

Havlovská 17

16000 Praha 6

prof. PhDr. Vlastimil Švec, CSc.

Pedagogická fakulta MU

Institut výzkumu školního vzdělávání

Poříčí 31

60300 Brno

svec@ped.muni.cz 